\title{
EDITORIALS
}

\section{A PUBLISHING MILESTONE}

With the appearance of its Winter, 1976 issue Cross Currents, "A Quarterly Review to explore the implications of Christianity for our times," reached a distinctive milestone-twenty-five years of publication. It seems appropriate for a fledgling journal like Horizons to note such an anniversary both with respect and perhaps even a little awe. It is not likely that Cross Currents will find for itself a biographer such as Commonweal has recently found in Rodger Van Allen (The Commonweal and American Catholicism, Fortress Press). Nonetheless the Cross Currents achievement is equally worthy of attention.

The journal first saw the light of day in December, 1950, long before Vatican II was even a glint in the eye of Pope John XXIII. It was preconciliar in its origins but decidedly conciliar (and at times even postconciliar) in terms of its innovative approach to Catholic journalism. Catholic it was and Catholic it remains, but always in the best and most catholic sense of the word. Over the years it has published the work of the likes of Tillich, Buber, Rahner, Berdyaev, Ricoeur, Pannikar, Guardini, Heschel, Fromm, Marcel, Merton, Niebuhr, Daniélou, Congar, Jung, Lonergan, and many others of similar stature. Initially emphasizing translations of European writing (most of us are not likely to have forgotten the longstanding dependence of American theological thought on European sources) Cross Currents has come to rely more and more on original articles reflective of the increasingly vigorous indigenous thinking now being done in the English-speaking world.

In a commemorative editorial Joseph Cunneen, the original and present editor-in-chief of the journal, remarks that "Cross Currents was begun by a group of young Catholic teachers and graduate students" and perhaps it would not be too wide of the mark to view the publication as primarily a venture in education and what we might today call consciousness-raising. Who can calculate the extent to which awareness has been altered by such an educational labor carried on over a quarter of a century!

This is ministry in its truest sense, service to the community in a personally meaningful form. No ordination was required or sought. No official approbation was extended or desired. Like Commonweal, Cross Currents involved from the beginning an initiative on the part of lay people, men and women. Ask not what the Church can do for you but what you can do for the Church even when uninvited! If you are asking what you can do for Cross Currents, an invaluable subscription can be 
had for a mere $\$ 6.50$ by writing to Cross Currents, 103 Van Houten Fields, West Nyack, New York 10994.

-DONALD P. GRAY

\section{ON READING THE BIBLE AS LITERATURE}

Since 1971 the National Council on Religion and Public Education (Administrative Offices: Ball State University, Muncie, Indiana, Dr. Daryl B. Adrian, Executive Director) has tried "to provide a forum and means for cooperation among organizations and institutions concerned with those ways of studying religion which are educationally appropriate and constitutionally acceptable to a secular program of public education." Several States have made it possible for teachers to be recognized in the area of teaching about religion, notably in social studies and literature curricula. Indiana University has been outstanding, under the leadership of James S. Ackerman and his associates, in preparing both teachers and materials for teaching the Bible as/in/and literature. Among the publications already available are Ackerman's On Teaching the Bible as Literature (English Curriculum Study Series), 1967; Kenneth R. R. Gros Louis, ed., Literary Interpretations of Biblical Narratives (The Bible in Literature Courses), 1974; and Roland Bartel, ed., Biblical Images in Literature (same series), 1975 (the last two books published by Abingdon Press).

This positive, constructive action has its critics. In the April twentythird issue of the National Catholic Reporter F. W. Nichols reviewed the two latter books listed above. In his article "Biblical Images in Literature" the reviewer called the second work "a ragbag collection of snippets from here and there on biblical themes." A long article by John A. Miles, Jr. in the Bulletin of the Council on the Study of Religion, (June, 1976), "The Debut of the Bible as a Pagan Classic," asks whether there will be any difference in teaching the Bible as a classic like the Iliad or the Odyssey, using Gilbert Highet's approach as a model. In the Summer 1975 issue of Christianity and Literature, Leland Ryken's lead essay, "Analyzing the Story of Abraham: Biblical Scholarship or Literary Criticism?" contrasts the methods of teaching the Bible as literature with the literary study of the Bible by biblical scholars.

It seems to me that many critics of the recent attempt to teach the Bible as/in/and literature are correct in their positions. It is true, to quote one, that "Teachers who know the Bible and who know literary criticism quite apart from biblical gimmickry are hard to come by and a serious business to train." I myself have witnessed efforts of teachers who know "literature" as taught in the schools, their knowledge stemming from a 